\title{
Verzeichnis
}

\section{der Herren, welche für den neunzehnten Band Referate geliefert haben.}

(Uie Verantwortlichkeit für den Inhalt der Referate tragen die Herren Referenten. Die in Klammern gesetzten Chiffern bezeichnen die Uebersetzer der in fremder Sprache eingesandten Referate.)
A. Herr Prof. August in Berlin.
B. $\quad$ Prof. Bruns in Leipzig.
Bb. " Professor Bobylew in
St. Petersburg.
Bg. \ Prof. Björling in Lund.
Bk. $~ D r . ~ B u k a$ in Charlottenburg.
Bm. ” Prof. v. Braunmühl in
München.
Cly. , Prof. Cayley in Cambridge.
Dn. " Dickstein in Warschau.
Dz. " Dr. Dziobek in Char-
E. Prof. G. Eneström in lottenburg.
Stockholm.
E. K. „ Dr. E. Kötter in Berlin.
El. " Prof. Engel in Leipzig.
F. $n$ Dr. Faerber in Berlin.
F. K. " Dr. F. Kötter in Berlin.
G. " Prof. v. Geer in ILeiden.
Gbs. " Assist. Prof. Gibs on in
Glr. " Prof. Glaisher in Cam-
Gm. „ Dr. Gram in Kopenhagen.
Gr. "Prof. Günther in München.
H. " Prof. Hoppe in Berlin.
Hch. " Dr. Henoch in Berlin.
Hk. " Prof. Hauck in Berlin.
Hr. $\quad$ Prof. Hamburger in Berlin.
Ht. " Dr. Hilbert in Königsberg
Lp. Herr Prof. Lampe in Berlin.
Ls. ॠ Lazarus in Hamburg.
M. $~$ Prof. F. Müller in Berlin.
Mi. \# Dr. Michaelis in Berlin.
M. L. " Prof. Mittag-Leffler in
Stockholm.
Mn. ॠ Prof. Mansion in Gent.
M-n. \# Prof. Mellin in Helsingfors.
Ms. " Professor Mestschersky
My. \# Prof. F. Meyer in Clausthal.
Mz. " Dr. Maynz in Ludwigslust.
N. " Prof. Neumann in Leipzig.
No. " Prof. Netto in Giessen.
P. $\quad$ Dr. Petzold in Hannover.
R. M. " Dr. R. M üller in Berlin.
Sbt. "Dr. Siebert in Gross-
Schg. Dr. Schlegel in Hagen.
Schn. , Prof Schumann in Berlin.
Scht $~ P r o f . S c h u b e r t$ in Hamburg.
Sn., Dr. P. Simon in Berlin.
Std. "Prof. Studnička in Prag.
T. Dr. Toeplitz in Breslau.
Tn. "Prof. Treutlein in
Tx. $\quad$ Prof. Teixeira in Porto.
V. "Dr. Valentiner in Kopen-
Vi. Dr. Vivanti in Mantua.
Hz. \ Prof. Hurwitz in Königs-
Wgt. " Professor Weingarten in
Wi. „Prof. A. Wassilieff in Berlin
Kazan.
K. „ Dr. Kobb in Stockholm.
Js. " Dr. Jolles in Aachen.
Kr. ॠ Prof. Krazer in Strassburg.
La. " Prof. Loria in Genua.
Lbg. " Prof. Lorberg in Strassburg.
Lg. \# Dr. Lange in Berlin.
Wn. „Prof. Wangerin in
Halle a. S.
W.St. „ Prof. W. Stahl in Aachen.
Wz. " Dr. Weltzien in Berlin.

Briefe und Zusendungen erbitten wir entweder durch Vermittelung der Verlagshandlung oder unter der Adresse:

Dr. Max Henoch, Berlin W, Victoriastr. 29. 